\title{
PEMANFAATAN LAHAN SEMPADAN SUNGAI BERBASIS SIG (SISTEM INFORMASI GEOGRAFIS)
}

\author{
Slamet Budiono ${ }^{1)}$, Anak Agung Sagung Alit W' ${ }^{1)}$ dan Moch. Shofwan ${ }^{1)}$ \\ ${ }^{1)}$ Program Studi Perencanaan Wilayah dan Kota, Fakultas Teknik Sipil dan Perencanaan (FTSP) \\ Universitas PGRI Adi Buana Surabaya \\ Email : shofwan.moch@gmail.com
}

\begin{abstract}
Abstrak
Daerah sempadan sungai berubah fungsi menjadi lahan permukiman maupun kegiatan ekonomi lainnya, yang disebabkan oleh tingginya urbanisasi. Salah satu daerah sempadan sungai yang banyak berubah fungsi tersebut adalah kawasan Sempadan Sungai Brantas Surabaya. Tujuan penulisan ilmiah ini adalah untuk mengetahui pemanfaatan lahan di daerah Sempadan Sungai Brantas. Metode yang digunakan adalah analisis deskriptif kualitatif untuk tata guna lahan di daerah kawasan sempadan sungai. Teknik analisis yang digunakan adalah berbasis SIG (Sistem Informasi Geografis). Hasilnya menunjukkan bahwa 48\% bangunan permanen yang berdiri dan didominasi kawasan industri dengan luas penggunaan lahan sebesar $138.231 \mathrm{~m}^{2}$ atau 29\%. Arahan dari penelitian ini adalah perlu adanya sosialisasi perijinan pemanfaatan lahan kawasan sempadan sungai dari pemerintah kepada masyarakat sekitar kawasan sempadan sungai Brantas Surabaya.
\end{abstract}

Kata Kunci : Pemanfaatan Lahan, Sempadan Sungai, Sistem Informasi Geografis.

\begin{abstract}
Abtract
Riparian areas changed into residential land or other economic activity, caused by the high rate of urbanization. One of area that many riparian change the functionality is the Border region Brantas River Surabaya. The purpose of this study was to examine the use of the land in the Brantas River Belt. The method used is descriptive qualitative analysis of land use in the river border region. The analysis technique used is based on GIS (Geographic Information System). The results of this study showed that $48 \%$ of permanent buildings standing and predominantly industrial zones with an area of $138231 \mathrm{~m}^{2}$ of land use or $29 \%$. Referrals from this research is the need for land use permits socialization riparian area of the government to the people around the area of Surabaya Brantas river border.
\end{abstract}

Keywords: Land Use, Border River, Geographic Information System. 


\section{PENDAHULUAN}

Peningkatan jumlah penduduk telah menyebabkan meningkatnya permintaan jumlah tempat tinggal. Permintaan yang tinggi akan tempat tinggal, kurang sebanding dengan luasan lahan yang tersedia. Masyarakat telah melakukan pemanfaatan lahan khususnya di kawasan sempadan sungai yang menurut peraturan perundangan yang berlaku larangan untuk didirikan bangunan (Setyadi dan Anton, 2013).

Dampak dari perkembangan kegiatan permukiman di sepanjang bantaran Kali Surabaya atau Sungai Brantas ini salah satunya adalah pencemaran air di badan sungai akibat buangan air limbah permukiman. Disisi lain Kali Surabaya atau Sungai Brantas merupakan sumber air bersih masyarakat Kota Surabaya. Sasaran dari implementasi strategi ini adalah pengendalian pencemaran lingkungan di bantaran Sungai Brantas Surabaya, peningkatan kualitas air Sungai Brantas Surabaya, pemenuhan prasarana sarana air limbah permukiman, dan peningkatan peran serta masyarakat (Fatnasari, Hylda dan Hermana J, 2010).

Perubahan penggunaan lahan adalah bertambahnya suatu penggunaan lahan dari satu sisi pengguna ke pengguna lahan yang lain dari suatu waktu ke waktu berikutnya, atau berubahnya fungsi suatu lahan pada kurun waktu yang berbeda (Wahyunto dkk, 2001). Perubahan penggunaan lahan dapat mempengaruhi sistem ekologi setempat diantaranya pencemaran air, polusi udara (Hu et al, 2008), perubahan iklim (Mahmood et al, 2009; Hu et al, 2008) berkurangnya keanekaragaman hayati (Sandin, 2009) dinamika aliran nitrat (Poor and McDonnell, 2007) serta fluktuasi pelepasan dan penyerapan $\mathrm{CO}_{2}$ (Canadell, 2002).

Selain itu, perubahan penggunaan lahan dipengaruhi karena pertumbuhan penduduk yang semakin pesat peningkatannya, serta adanya tuntutan pemenuhan salah satu kebutuhan primer yaitu mempunyai tempat tinggal yang layak. Namun seiring perkembangan era globalisasi, lahan yang tersedia semakin sempit bahkan tidak cukup untuk memenuhi kebutuhan penduduk yang semakin pesat. Pada akhirnya penduduk memanfaatkan daerah sempadan sungai untuk mendirikan tempat tinggal serta aktifitas lainnya.

Sistem Informasi Geografis (SIG) adalah sistem berbasis komputer yang terdiri atas perangkat keras komputer (hardware), perangkat lunak (software), data geografis dan sumberdaya manusia (brainware) yang mampu merekam, menyimpan, memperbaharui, menampilkan dan menganalisis informasi yang bereferensi geografis (Jaya, 2002). Penggunaan SIG terutama berkaitan dengan kemampuannya dalam menggabungkan berbagai data yang berbeda struktur, format dan tingkat ketepatan.

Sehingga memungkinkan integrasi berbagai disiplin keilmuan yang sangat diperlukan dalam mengkaji pemanfaatan lahan yang ada dan dapat dilakukan lebih cepat.

Tujuannya adalah untuk mengetahui pemanfaatan lahan di daerah Sempadan Sungai Brantas. Adapun rencana pemecahan masalah adalah dengan mengidentifikasi pemanfaatan lahan kawasan sempadan sungai, meliputi:

1. Pemanfaatan lahan kawasan sempadan sungai meliputi;

a). Pola Penggunaan Lahan;

b). Kondisi Fisik Lahan, sebagai kawasan Permukiman, Pendidikan, Ruang Publik atau Ruang Terbuka Hijau.

Perubahan penggunaan lahan adalah bertambahnya suatu penggunaan lahan dari satu sisi pengguna ke pengguna lahan yang lain dari suatu waktu ke waktu berikutnya, atau berubahnya fungsi suatu lahan pada kurun waktu yang berbeda (Wahyunto dkk, 2001). Perubahan penggunaan lahan dapat mempengaruhi sistem ekologi setempat diantaranya pencemaran air, polusi udara $(\mathrm{Hu}$ et al, 2008) perubahan iklim (Mahmood et al, 2009; Hu et al, 2008) berkurangnya keanekaragaman hayati (Sandin, 2009) dinamika aliran nitrat ( Poor and McDonnell, 2007) serta fluktuasi pelepasan dan penyerapan $\mathrm{CO}_{2}$ (Canadell, 2002).

Selain itu, perubahan penggunaan lahan dipengaruhi karena pertumbuhan penduduk yang semakin pesat peningkatannya, serta adanya tuntutan pemenuhan salah satu kebutuhan primer 
yaitu mempunyai tempat tinggal yang layak. Namun seiring perkembangan era globalisasi, lahan yang tersedia semakin sempit bahkan tidak cukup untuk memenuhi kebutuhan penduduk yang semakin pesat. Pada akhirnya penduduk memanfaatkan daerah sempadan sungai untuk mendirikan tempat tinggal serta aktifitas lainnya. Penggunaan lahan di perkotaan sangat majemuk, berbeda dengan di pedesaan. Hal ini disebabkan karena mata pencaharian di perkotaan sangat beragam.

Sempadan sungai digunakan oleh sebagian masyarakat sebagai lahan pembangunan industri dan permukiman serta lahan pertaniaan. Menurut Dinas Pengairan Provinsi saat ini terdapat 1.443 bangunan permukiman penduduk dan 109 industri di sempadan Kali Surabaya.
Pengalihan pemanfaatan lahan sempadan sungai menjadi lahan industri dan permukiman akan menghilangkan fungsi ekologis daerah sempadan sungai sebagaimana telah diuraikan di atas. Pembangunan permukiman di atas lahan sempadan sungai juga menimbulkan resiko bagi penghuni karena adanya genangan air periodik pada musim hujan dan lahan sempadan yang cenderung labil dan rawan akan longsor akan membahayakan masyarakat penghuni di sempadan sungai (Dinas Pengairan Provinsi Jawa Timur, 2013).

Pengembangan permukiman diarahkan pada wilayah barat, mengingat kecukupan luas lahan yang belum terbangun. Peraturan tentang sempadan sungai tentang kawasan Unit Pengembangan Ahmad Yani dapat dilihat pada tabel 1 .

Tabel 1. Pengaturan Sempadan Sungi Wilayah Perkotaan

\begin{tabular}{clcl}
\hline No & \multicolumn{1}{c}{ Jenis Sungai } & \multicolumn{1}{c}{ Sempadan } & \multicolumn{1}{c}{ Keterangan } \\
\hline A & Sungai Bertanggul di dalam Perkotaan & $5 \mathrm{~m}$ & Dari sisi luar kaki tanggul \\
$\mathbf{1}$ & Sungai Besar & $3 \mathrm{~m}$ & Dari sisi luar kaki tanggul \\
$\mathbf{2}$ & Sungai Kecil & $10 \mathrm{~m}$ & $\begin{array}{l}\text { Dihitung dari tepi sungai pada waktu } \\
\text { ditetapkan }\end{array}$ \\
$\mathbf{B}$ & Sungai Tidak Bertanggul di dalam Perkotaan \\
$\mathbf{1}$ & Sungai dengan kedalaman $<3 \mathrm{~m}$ & $15 \mathrm{~m}$ & $\begin{array}{l}\text { Dihitung dari tepi sungai pada waktu } \\
\text { ditetapkan }\end{array}$ \\
$\mathbf{2}$ & Sungai dengan kedalaman $3-20 \mathrm{~m}$ & Dihitung dari tepi sungai pada waktu \\
$\mathbf{3}$ & Sungai dengan kedalaman $>20 \mathrm{~m}$ & $30 \mathrm{~m}$ & \begin{tabular}{l} 
ditetapkan \\
\hline
\end{tabular} \\
\hline
\end{tabular}

Sumber: RDTRK UP. Ahmad Yani, 2010.

Sistem Informasi Geografis (SIG) adalah sistem berbasis komputer yang terdiri atas perangkat keras komputer (hardware), perangkat lunak (software), data geografis dan sumberdaya manusia (brainware) yang mampu merekam, menyimpan, memperbaharui, menampilkan dan menganalisis informasi yang bereferensi geografis (Jaya, 2002).

\section{METODE}

Jenis pengamatan yang digunakan dalam pemanfaatan lahan di daerah sempadan sungai adalah dengan menggunakan metode penelitian analisis deskriptif kualitatif. Metode analisis deskriptif kualitatif sering disebut metode penelitian naturalistik karena penelitiannya dilakukan dengan kondisi alamiah. Sering juga disebut sebagai paradigma interpretif/konstruktif, yang memandang realitas sosial sebagai sesuatu yang holistik/utuh, kompleks, dinamis, penuh makna, dan bersifat interaktif. Penelitian dilakukan pada objek yang tidak dimanipulasi oleh peneliti dan kehadiran peneliti tidak mempengaruhi dinamika pada objek tersebut. Metode kualitatif digunakan untuk mendapatkan data yang mendalam/data yang sebenarnya.

Metode kualitatif peneliti sebagai human instrument dan dengan teknik pengumpulan data participant observation dan in depth interview, maka peneliti harus berinteraksi dengan sumber data (Sugiyono, 2011).

Penelitian ini dibatasi pada pemanfaatan lahan di sepanjang daerah 
sempadan aliran sungai Brantas, perbatasan Kecamatan Jambangan dengan Kecamatan Karang Pilang Kota Surabaya sejauh 2 kilometer terhitung dari batas sebelah utara adalah jalan tol Gunungsari sampai dengan sebelah selatan adalah pom bensin Kebonsari.
Adapun batas Administrasi Sungai Brantas ini berada diantara dua kecamatan yang berdampingan yaitu Kecamatan Karang Pilang dan Kecamatan Jambangan Kota Surabaya.

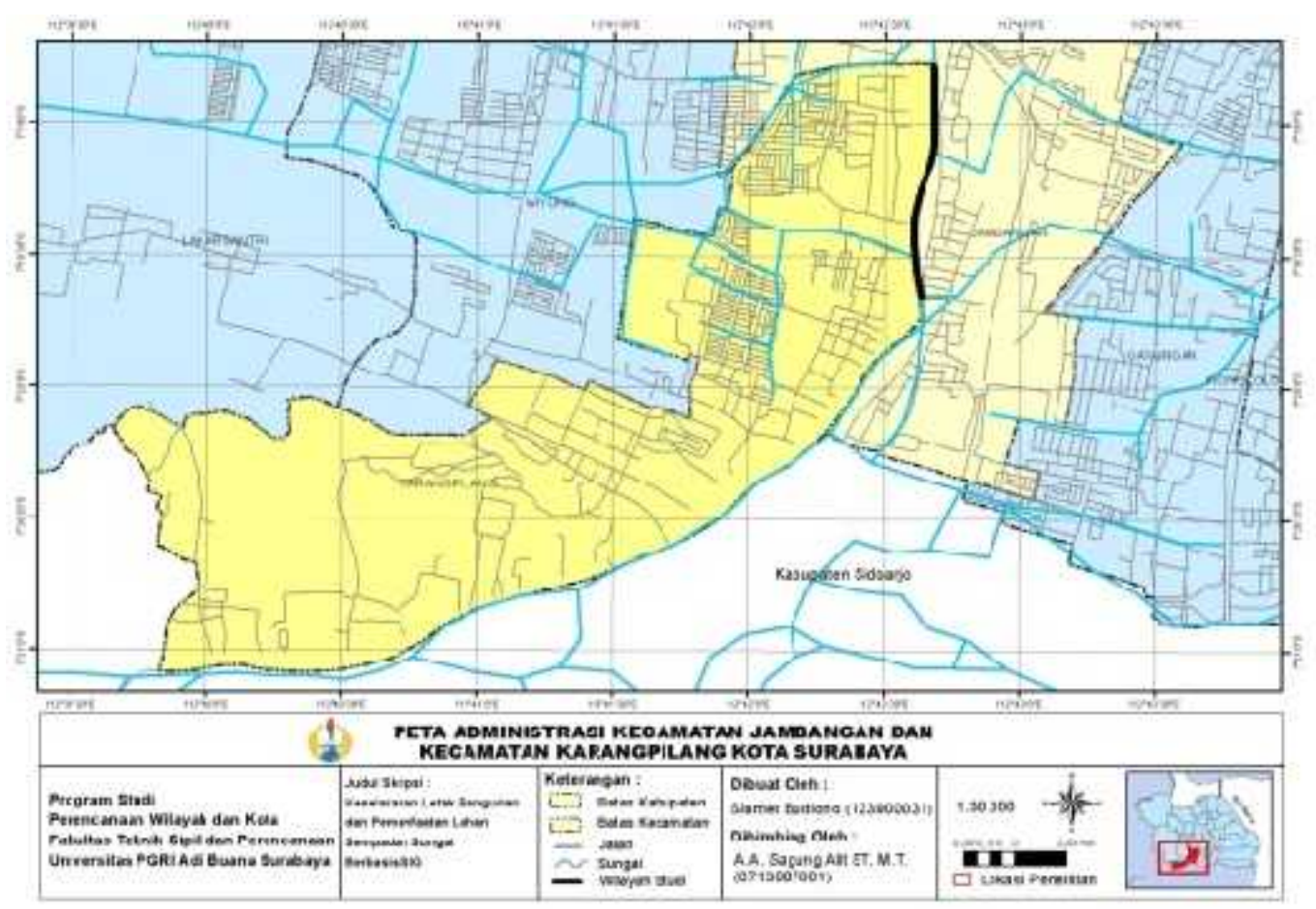

Gambar 1. Peta Administrasi Kecamatan Jambangan dan Karangpilang

Batas administrasi Kecamatan Jambangan adalah sebagai berikut:

Sebelah Utara : Kecamatan Wonokromo

Sebelah Timur : Kecamatan Gayungan

Sebelah Selatan : Kota Sidoarjo

Sebelah Barat : Kecamatan Karangpilang

Batas administrasi Kecamatan Karang

Pilang adalah sebagai berikut :

Sebelah Utara : Kecamatan Wiyung

Sebelah Timur : Kecamatan Jambangan

Sebelah Selatan : Kota Sidoarjo

Sebelah Barat : Kota Gresik

Adapun batasan fisik wilayah

penelitian sebagai berikut:

$\begin{array}{ll}\text { Utara } & \text { : Jalan Tol Gunung Sari } \\ \text { Barat } & \text { : Jalan Raya Jambangan } \\ \text { Selatan } & \text { : Pom bensin Kebonsari } \\ & \text { Kecamatan Jambangan } \\ \text { Timur } & \text { : Jalan Raya Mastrip }\end{array}$

Gambar Wilayah Studi 1.

Tujuan utama dari definisi variabel operasional adalah untuk menghindari penafsiran ganda (double definition) terhadap variabel-variabel dalam penelitian, adapun definisi operasional variabel penelitian ini adalah sebagai berikut:

1. Penggunaan Lahan Kawasan Sempadan Sungai

a. Penggunaan Lahan adalah bertambahnya suatu penggunaan lahan dari satu sisi pengguna ke pengguna lahan yang lain dari suatu waktu ke waktu berikutnya, atau berubahnya fungsi suatu lahan pada kurun waktu yang berbeda ;

b. Kondisi Fisik Lahan adalah kondisi fisik lahan serta penggunaan lahan saat ini yang berada diatas tempat dimana penelitian sedang dilakukan.

Metode yang digunakan peneliti adalah analisis deskriptif kualitatif untuk tata guna lahan yang dijelaskan sebagai berikut:

1. Analisis Tata Guna Lahan. 
Analisis Tata Guna Lahan adalah suatu analisis yang dilakukan untuk mengetahui kondisi eksisting penggunaan lahan yang ada pada wilayah studi, analisis ini juga menggunakan analisis deskriptif kualitatif dikarenakan metode analisis ini sering disebut metode penelitian naturalistik karena penelitiannya dilakukan dengan kondisi alamiah. Sering juga disebut sebagai paradigma interpretif/ konstruktif, yang memandang realitas sosial sebagai sesuatu yang holistik/ utuh, kompleks, dinamis, penuh makna, dan bersifat interaktif. Penelitian dilakukan pada objek yang tidak dimanipulasi oleh peneliti dan kehadiran peneliti tidak mempengaruhi dinamika pada objek tersebut. Metode kualitatif digunakan untuk mendapatkan data yang mendalam/ data yang sebenarnya.

Metode kualitatif peneliti sebagai human instrument dan dengan teknik pengumpulan data participant observation dan in depth interview, maka peneliti harus berinteraksi dengan sumber data (Sugiyono, 2011).

2. Analisis Sistem Informasi Geografis (SIG)

Analisis Sistem Informasi Geografis (SIG) merupakan sistem informasi berbasis komputer yang digunakan secara digital untuk menggambarkan dan menganalisa ciri-ciri geografi yang digambarkan pada permukaan bumi dan kejadian-kejadiannya (atribut-atribut non spasial untuk dihubungkan dengan studi mengenai geografi) (Tuman, 2001).

a. Peta Digital

Peta digital adalah memindahkan peta

kertas (manuskrip) kedalam format yang dapat dibaca oleh komputer ( peta digital

) dengan alat digitasi (digitizer). Era informasi ditandai dengan pemanfaatan teknologi komputer, teknologi komunikasi dan teknologi proses secara terintegrasi. Informasi spasial adalah salah satu informasi yang harus ada.

b. Data spasial

Data spasial merupakan data yang berhubungan dengan jarak dan keruangan. Untuk merepresentasikan objek-objek seperti bentuk bangunan, batas-batas persil tanah milik, batas administrasi, garis-garis jalan raya, sungai, posisi pilar, dan sebagainya dilakukan oleh komputer dengan memanipulasi objek dasar atau entityyang memiliki atribut geometri. Dengan demikian, data spatial direpresentasikan di dalam basis data dalam bentuk model data raster dan model data vektor.

c. Model data raster

Model data raster menampilkan, menempatkan, dan menyimpan data spatial dengan menggunakan struktur matriks atau piksel-piksel yang membentuk grid. Setiap piksel (sel grid) atau sel ini memiliki atribut tersendiri, termasuk koordinatnya yang unik (disudut grid, dipusat grid, atau di tempat yang lainnya). Model raster memberikan informasi spatial (informasi mengenai jarak dan keruangan) apa yang terjadi dimana saja dalam bentuk gambaran yang digeneralisir.

d. Layer

Komputer tidak dapat mengerti mengenai esensi dari bentuk bangunan, batas-batas persil tanah milik, batas administrasi, garis-garis jalur pendakian, sungai dan sebagainya.Untuk merepresentasikan objek-objek diatas yang dapat dilakukan oleh komputer adalah memanipulasi objek dasar atau entity yang memiliki atribut geometri. Nilai-nilai piksel-piksel ini kemudian bekerja sama dalam membentuk layer(s) data spasial. Basis data spasial mengandung lebih dari satu layer. Setiap layer akan bersifat kongruen terhadap layer(s) yang lain (Prahasta, 2002).

\section{HASIL DAN PEMBAHASAN}

3.1 Pola Penggunaan Lahan Kawasan Sempadan Sungai Brantas Surabaya Penggunaan lahan kawasan sempadan sungai Brantas Surabaya banyak yang dimanfaatkan sebagai kawasan permukiman penduduk, yang mana kawasan sempadan sungai adalah kawasan yang digunakan untuk melindungi kualitas dan kebersihan sungai. Adapun peta implementasi penggunaan lahan kawasan sempadan Sungai Brantas Surabaya dapat dilihat pada gambar 2 . 


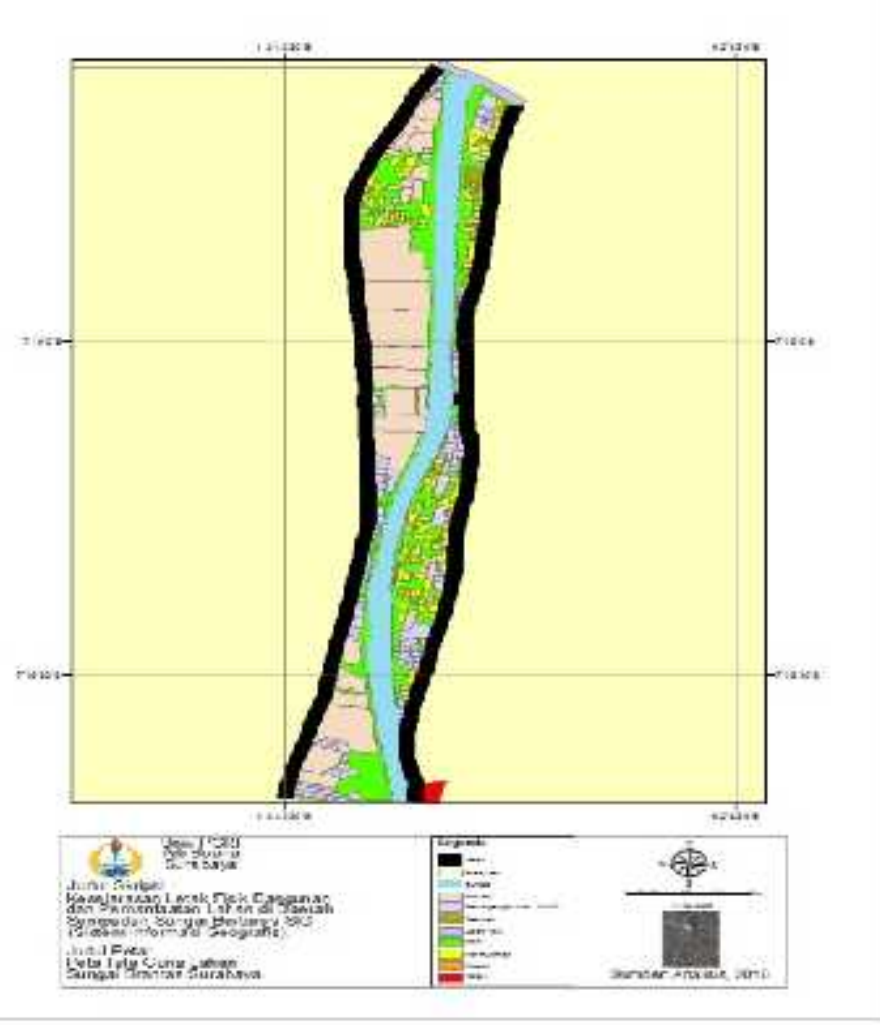

Gambar 2. Peta Tata Guna Lahan Sungai Brantas Surabaya Tahun 2016

Kawasan industri memiliki penggunaan lahan paling banyak dikarenakan pada Kecamatan Karang Pilang memang mayoritas penggunaan lahan dan menurut Unit Pengembangan Wilayahnya merupakan kawasan industri. Peta pola guna lahan kawasan sempadan Sungai Brantas Surabaya dapat dilihat pada gambar 3, 4, 5 dan 6 dengan pembagian persegmentasi.

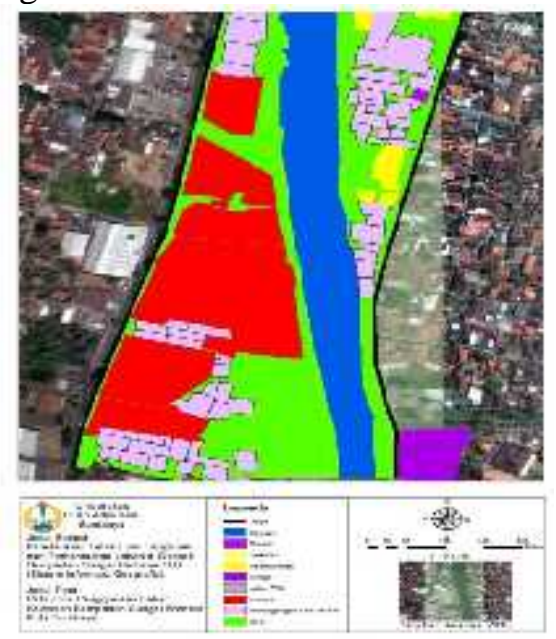

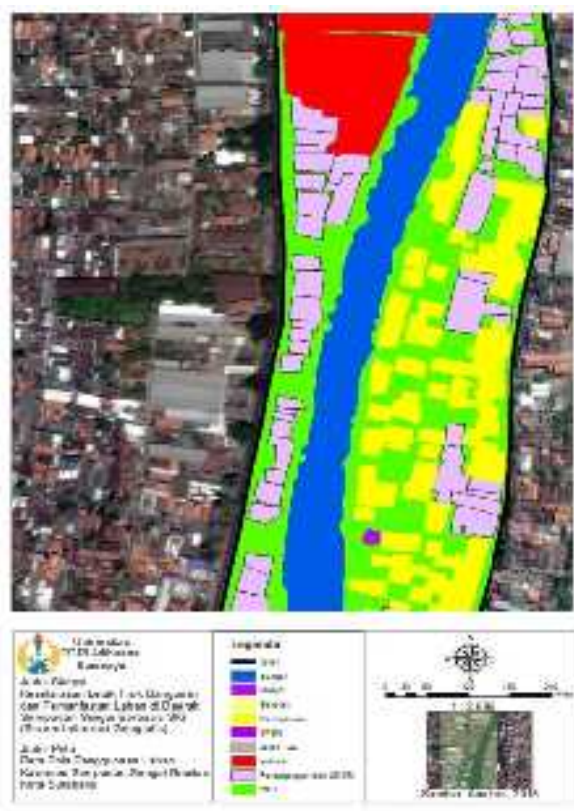

Gambar 4. Pola Penggunaan Lahan Kawasan Sempadan Sungai Brantas Surabaya (Segmen 2).

Gambar 3. Pola Penggunaan Lahan

Kawasan Sempadan Sungai Brantas Surabaya (Segmen 1). 


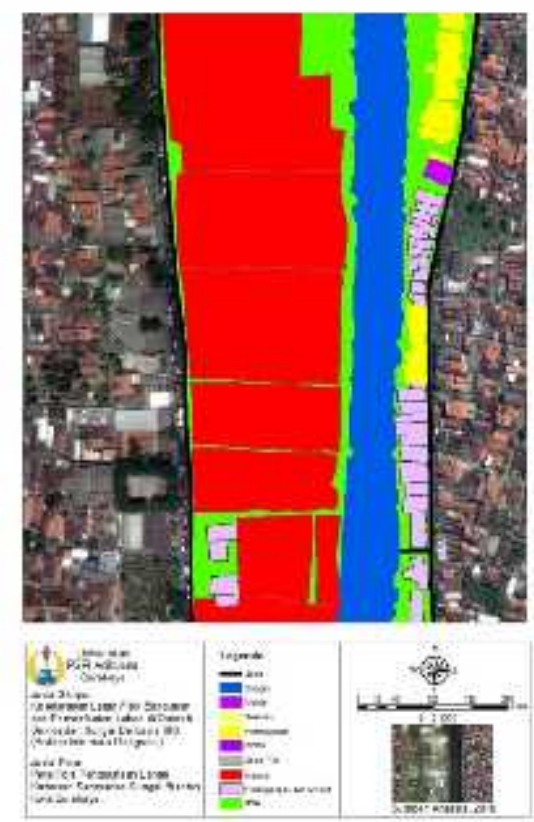

Gambar 5. Pola Penggunaan Lahan Kawasan Sempadan Sungai Brantas Surabaya (Segmen 3).

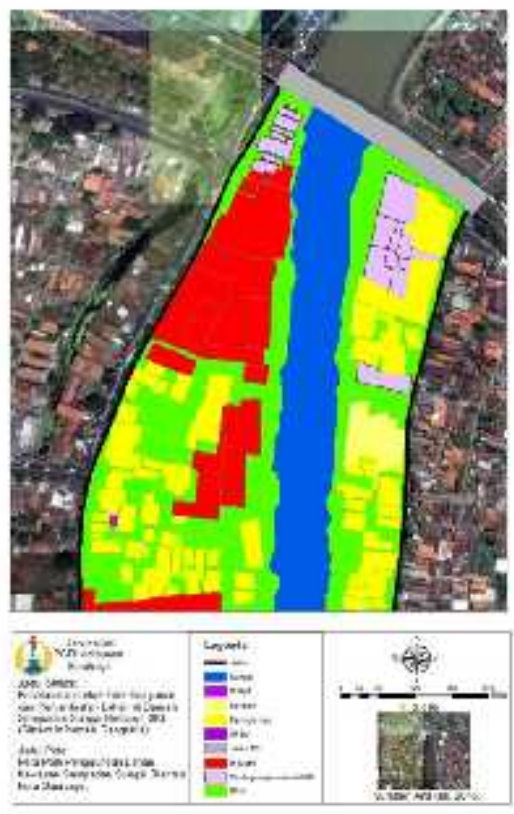

Gambar 6. Pola Penggunaan Lahan Kawasan Sempadan Sungai Brantas Surabaya (Segmen 4).

\section{a). Ruang Terbuka Hijau}

Kawasan ruang terbuka hijau sempadan adalah kawasan yang berfungsi untuk melindungi kawasan sempadan sungai Brantas Surabaya, penyajian data kawasan ruang terbuka hijau sempadan sungai Brantas Surabaya dapat dilihat pada table 3 .
Tabel 3. Luas Penggunaan Lahan $\left(\mathrm{m}^{2}\right)$ Ruang Terbuka Hijau Kawasan Sempadan Sungai Brantas Surabaya Tahun 2016

\begin{tabular}{lr}
\hline Penggunaan Lahan & Luas RTH $\left.\mathbf{( m}^{\mathbf{2}}\right)$ \\
\hline Lapangan & 3.908 \\
RTH sempadan & 86.255 \\
Lain-lain & 37.712 \\
Total & $\mathbf{1 2 7 . 8 7 5}$ \\
\hline
\end{tabular}

Pada tabel 3 dapat disimpulkan bahwa kawasan ruang terbuka hijau di daerah kawasan sempadan Sempadan Sungai Brantas ini dengan total luas penggunaan lahan adalah 127.875 meter persegi $\left(\mathrm{m}^{2}\right)$ dengan pembagian luasan paling banyak adalah penggunaan lahan RTH sempadan sungai dengan luas 86.255 meter persegi $\left(\mathrm{m}^{2}\right)$ seperti pada tabel tersebut masih menjadi penyeimbang kawasan sempadan sungai dengan luasan yang masih banyak di daerah sempadan Sungai Brantas Surabaya, sehingga dapat menjaga ekosistem dan kebersihan serta kualitas Sungai Brantas Surabaya.

\section{b). Permukiman}

Kawasan permukiman adalah kawasan yang juga banyak terbangun di kawasan sempadan Sungai Brantas Surabaya, penyajian data kawasan permukiman yang ada di kawasan sempadan Sungai Brantas Surabaya dapat dilihat pada table 4 .

Tabel 4. Luas Permukaan $\left(\mathrm{m}^{2}\right)$ Kawasan Sempadan Sungai Brantas Surabaya Tahun 2016

\begin{tabular}{cr}
\hline Segmentasi & Luas Permukiman $\left(\mathbf{m}^{\mathbf{2}}\right)$ \\
\hline 1 & 1.299 \\
2 & 20.324 \\
3 & 2.418 \\
4 & 20.846 \\
Total & $\mathbf{4 4 . 8 8 7}$ \\
\hline
\end{tabular}

Pada tabel 4 dapat dilihat bahwa kawasan permukiman juga masih banyak terbangun disekitar kawasan sempadan Sungai Brantas Surabaya. Dengan luas penggunaan lahan mencapai 44.887 meter persegi $\left(\mathrm{m}^{2}\right)$ atau sekitar $10 \%$ dari luas penggunaan lahan di sempadan Sungai Brantas Surabaya. Kawasan Permukiman 
banyak terbangun di kawasan sempadan Sungai Brantas Surabaya ini di karenakan banyaknya bangunan atau rumah masyarakat khususnya Kecamatan Jambangan yang menurut Unit Pengembangan A.Yani, Kecamatan Jambangan memang kawasan permukiman.

\section{c). Perindustrian}

Kawasan perindustrian adalah kawasan yang banyak terbangun di kawasan sempadan Sungai Brantas Surabaya, penyajian data kawasan perindustrian yang ada pada kawasan sempadan sungai Brantas Surabaya dapat dilihat pada tabel 5 .

Tabel 5. Segmentasi Luas Perindustrian (m2) dan Persentase (\%) Kawasan Perindustrian Sempadan Sungai Berantas Surabaya Tahun 2016

\begin{tabular}{cr}
\hline Segmentasi & Luas Industri $\left.\mathbf{( m}^{\mathbf{2}}\right)$ \\
\hline 1 & 31.967 \\
2 & 7.949 \\
3 & 71.055 \\
4 & 17.327 \\
Total & $\mathbf{1 2 8 . 2 9 8}$ \\
\hline
\end{tabular}

Pada tabel 5 dapat disimpulkan bahwa kawasan industri merupakan kawasan yang memiliki luas penggunaan lahan terbesar di daerah Sempadan Sungai Brantas Surabaya, dengan luas 128.298 meter persegi $\left(\mathrm{m}^{2}\right)$ atau mencapai $29 \%$ dari total luas wilayah sempadan Sungai Brantas Surabaya dan dapat dilihat bahwa luas wilayah pada segmentasi 3 paling banyak dengan luas wilayah 71.055 meter persegi $\left(\mathrm{m}^{2}\right)$ dan dengan persentase $55 \%$ dari total luas wilayah industri pada kawasan sempadan Sungai Brantas Surabaya. Kawasan industri banyak terbangun pada kawasan sempadan sungai Brantas Surabaya karena pada Kacamatan Karang Pilang menurut Unit Pengembangan Wiyung merupakan kawasan industri.

\section{d). Perdagangan dan Jasa}

Kawasan perdagangan dan jasa juga banyak terbangun di kawasan sempadan Sungai Brantas Surabaya, penyajian data kawasan sempadan Sungai Brantas Surabaya dapat dilihat pada tabel 6 .
Tabel 6. Sedimentasi Luas Kawasan Perdagangan dan Jasa $\left(\mathrm{m}^{2}\right)$ dan Persentase (\%) Kawasan Perdagangan dan Jasa Sempadan Sungai Brantas Surabaya Tahun 2016

\begin{tabular}{cr}
\hline Segmentasi & Luas Industri $\left(\mathbf{m}^{\mathbf{2}}\right)$ \\
\hline 1 & 17.972 \\
2 & 24.808 \\
3 & 7.916 \\
4 & 1.232 \\
Total & $\mathbf{5 1 . 9 2 8}$ \\
\hline
\end{tabular}

Pada tabel 6 dapat dilihat bahwa kawasan perdagangan dan jasa di daerah Sempadan Sungai Brantas Surabaya sebesar 51.928 meter persegi $\left(\mathrm{m}^{2}\right)$ atau mencapai $12 \%$ dari luas penggunaan lahan di daerah sempadan Sungai Brantas Surabaya dengan pembagian luasan persegmen yang diuraikan pada gambar berikut untuk memudahkan dalam menganalisis. Kawasan perdagangan dan jasa juga banyak terbangun di kawasan sempadan Sungai Brantas Surabaya dikarenakan masyarakat sekitar juga memanfaatkan tempat tinggalnya sebagai tempat kegiatan untuk berdagang dan menjualkan jasa.

\section{e). Fasilitas Umum}

Fasilitas Umum adalah salah satu tempat pada kawasan sempadan sungai Brantas Surabaya yang digunakan masyarakat untuk kegiatan maupun beribadah, penyajian data fasilitas umum yang ada di kawasan sempadan Sungai Brantas Surabaya dapat dilihat pada gambar 7 .

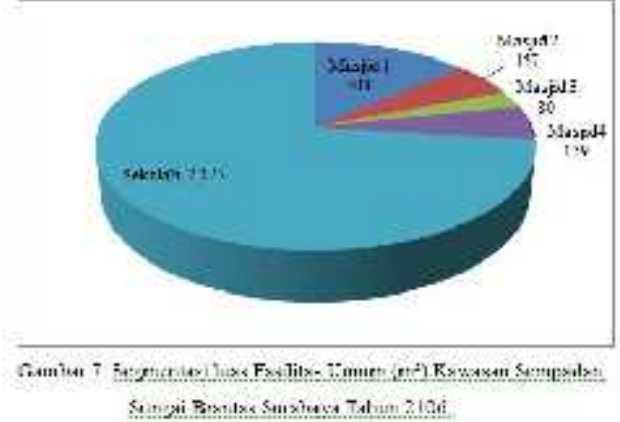

Pada gambar 7 dapat dilihat bahwa Fasilitas Umum di daerah sempadan Sungai Brantas Surabaya ini masih kurang memadai karena melihat penggunaan lahan yang ada hanya masih tersedia 4 tempat peribadatan dan 1 tempat pendidikan dengan luas penggunaan lahan sekitar 2.979 
meter persegi $\left(\mathrm{m}^{2}\right)$ atau sekitar $0,63 \%$ dari luas wilayah di daerah sempadan Sungai Brantas Surabaya. Dengan banyaknya kawasan permukiman yang terbangun di kawasan sempadan Sungai Brantas Surabaya dan kurangnya fasilitas umum yang ada, maka dibutuhkan peran serta pemerintah setempat dan masyarakat untuk bersinergi memenuhi kebutuhan penggunaan lahan untuk menambah kawasan fasilitas umum.

\section{KESIMPULAN}

Berdasarkan analisis dan pembahasan sebelumnya dapat diambil kesimpulan bahwa pemanfaatan lahan kawasan sempadan Sungai Brantas Surabaya lebih banyak didominasi oleh kawasan industri yaitu sebesar $128.298 \mathrm{~m}^{2}$ atau $29 \%$ dari luas keseluruhan penggunaan lahan kawasan sempadan Sungai Brantas Surabaya, sedangkan untuk luas penggunaan lahan kawasan Fasilitas Umum masih sedikit dengan luas penggunaan lahan sebesar $2.979 \mathrm{~m}^{2}$. Sedangkan untuk ruang terbuka hijau sebesar $127.875 \mathrm{~m}^{2}$, permukiman sebesar $44.887 \mathrm{~m}^{2}$, perdagangan dan jasa sebesar $51.928 \mathrm{~m}^{2}$ dan luas sungai sebesar $88.101 \mathrm{~m}^{2}$. Dengan jumlah penggunaan lahan kawasan Sungai Brantas Surabaya sebesar $444.068 \mathrm{~m}^{2}$.

\section{Ucapan Terima Kasih}

Ucapan terimakasih ditujukan kepada

Pimpinan Fakultas, Ketua Jurusan Perencanaan Wilayah dan Kota, Universitas PGRI Adi Buana Surabaya.

\section{DAFTAR PUSTAKA}

Canadell, J.G. 2002.'Land use effects on terrestrial carbon sources and sinks". Science in China (Series C),45. 1-9;

Dinas Pengairan Provinsi Jawa Timur, 2013;

Fatnasari, Hylda dan Hermana J. 2010. Strategi Pengelolaan Air Limbah Permukiman di Bantaran Kali Surabaya. FTL-ITS. Surabaya;

Hu, D., G. Yang, Q. Wu, H. Li, X. Liu, X. Niu, Z. Wang, and Q. Wang. 2008.”Analyzing Land Use Changes in the Metropolitan Jilin City of Northeastern China Using Remote Sensing and GIS". Sensor, 8. 5449-5465;

Jaya, I.N. S. 2002. Penginderaan Jauh Satelit untuk Kehutanan. Laboratorium Inventarisasi Hutan, Jurusan Manajemen Hutan, Fakultas Kehutanan IPB;

Mahmood, R., R.A. Pielke Sr., K.G. Hubbard, D. Niyogi, G. Bonan, P. Lawrence, B. Baker,R. McNider, C. McAlpine, A. Etter, S. Gameda, B. Qian, A. Cartelon, A.Beltran-Przekurat, T. Chase, A.I. Quintanar, J.O.Adegoke, S. Vezhapparambu, G. Conner, S. Asefi, E. Sertel, D.R. Legates, Y. Wu, R. Hale, O.W. Frauenfeld, A. Watts, M. Shepherd, C. Mitra, V.G. Anantharaj, S. Fall, R. Lund, A. Trevino, P. Blanken.2008. "Land Cover Change on Climate and Future Research Priorities". Bulletin of the American Meteorological Society: In Press;

Poor, C.J., J.J. McDonnell. 2007. "The effects of land use on stream nitrate dynamics". Journal of Hidrology, 332. 54-68;

Prahasta, Eddy. 2001. Konsep-Konsep Dasar Sistem Infomasi Geografis. Informatika, Bandung;

Sandin, L. 2009. "The relationship between land-use, hydromorphology and river biota at different spatial and temporal scales: a synthesis of seven case studies". Fundamental and Applied Limnology. Vol 174/1: 1-5;

Setyadi, Anton. 2013. Analisis Keselarasan Letak Bangunan dan Pemanfaatan Lahan Terhadap Peraturan Sempadan Sungai Menggunakan Citra Satelit Quickbird. Jurnal Publikasi Ilmiah FGEOGRAFI - UM Surakarta, Surakarta;

Sugiyono. 2011. Metode Penelitian Kuantitatif, Kualitatif, dan R\&D. Alfabeta, Bandung;

Tuman. 2001. Overview of GIS. http:www.gisdevelopment.net/tutorials/tuman006.htm;

Wahyunto, M. Z. Abidin, A. Priyono dan Sunaryanto. 2001. Studi Perubahan Penggunaan Lahan DAS Citarik, Jawa Barat Dan DAS Garong Jawa Timur. Makalah Seminar Nasional Multifungsi Lahan Sawah, Asean Secretariate Maff Japan \& Puslitbang Tanah dan Agroklimat Bogor; 